\title{
PENGARUH PENERAPAN TATA TERTIB SEKOLAH TERHADAP TINGKAT KEDISIPLINAN SISWA KELAS X SMA PERSIAPAN STABAT TAHUN PEMBELAJARAN 2017/2018
}

\author{
Ardian Abdi \\ STKIP Budidaya Binjai
}

\begin{abstract}
Abstrak
Penelitian ini bertujuan untuk mengetahui ada atau tidaknya pengaruh Pengaruh penerapan tata tertib sekolah terhadap tingkat kedisiplinan Siswa kelas X di SMA Persiapan Stabat Tahun Pembelajaran 2018/2019. Penelitian ini adalah penelitian Quasi Eksperimen. Sampel dalam penelitian ini adalah siswa kelas X SMA Persiapan Stabat tahun pelajaran 2018/2019 sebanyak 35 siswa. Berdasarkan hasil analisis data diketahui nilai t hitung $>\mathrm{t}$ tabel sehinnga dapat diambil kesimpulan bahwa terdapat pengaruh penerapan tata tertib sekolah terhadap tingkat kedisiplinan siswa kelas X di SMA Persiapan Stabat tahun pembelajaran 2018/2019.
\end{abstract}

\section{PENDAHULUAN}

Mohamad Mustari mengatakan dunia pendidikan saat ini menghadapi berbagai masalah yang amat kompleks yang perlu mendapatkan perhatian semua orang. Salah satu masalah tersebut adalah menurunnya tata krama kehidupan sosial dan etika moral dalam praktik kehidupan sekolah yang mengakibatkan sejumlah ekses negatif yang sangat merisaukan masyarakat. Akses tersebut antara lain semakin maraknya penyimpangan berbagai norma kehidupan agama dan sosial kemasyarakatan yang terwujud dalam bentuk kurang hormat kepada guru dan pegawai sekolah, kurang disiplin terhadap waktu dan tidak mengindahkan peraturan, kurang memelihara keindahan dan kebersihan lingkungan, perkelahian antar pelajar, penggunaan obat terlarang dan lain-lainnya.

Masalah ini bilamana tidak segera diatasi akan semakin mengancam kehidupan generasi bangsa khususnya dan tata kehidupan sosial masyarakat pada umumnya. "Undangundang Republik Indonesia No 20 Tahun 2003 tentang Sistem Pendidikan Nasional dalam Pasal 7 dinyatakan bahwa orang tua berhak berperan serta dalam memilih satuan pendidikan dan memperoleh informasi tentang perkembangan pendidikan anaknya. Orang tua dari anak usia wajib belajar, berkewajiban memberikan pendidikan dasar kepada anaknya, serta masyarakat berkewajiban memberikan dukungan sumber daya dalam penyelenggaraan pendidikan.

Sebagaimana diketahui, bahwa pendidikan budi pekerti secara konsepsional dapat dibagi dalam dua aspek yang dipersepsi dan yang diwujudkan. Telah disepakati bahwa pendidikan budi pekerti yang dipersepsi dan diajarkan dimasukkan dan diintegrasikan kedalam mata pelajaran yang relevan (Pendidikan Agama, PPKn, Bahasa Indonesia). Namun demikian, tujuan akhir adalah bagaimana pendidikan budi pekerti menjadi bagian yang diterapkan dalam kehidupan sehari-hari di sekolah.

Sekolah sebagai suatu lembaga pendidikan merupakan small community, suatu masyarakat dalam skala kecil sehingga gagasan untuk mewujudkan masyarakat yang taat akan norma perlu diwujudkan dalam tata kehidupan sekolah, yang salah satunya melalui pendidikan budi pekerti yang nyata dilakukan, bukan semata-mata yang dipersepsi. Oleh karena itu, setiap sekolah mulai saat ini perlu mulai memikirkan bagaimana mewujudkan 
pendidikan budi pekerti agar anak didik betul-betul dapat menerapkan norma dan tata nilai yang sesuai dengan agama dan budaya bangsa.

Sekolah merupakan tempat pendidikan setelah lingkungan keluarga. Sekolah sebagai lembaga pendidikan mempunyai tanggung jawab besar untuk mencapai tujuan pendidikan. Di sekolah dikembangkan aturan yang berlaku untuk mengatur kedudukan dan peranan seseorang sesuai dengan tujuan pendidikan yang akan dicapai. Sekolah juga bertugas membentuk kepribadian siswa agar mempunyai kepribadian yang luhur, mulia, serta berdisiplin yang tinggi. Sekolah menjadi sarana yang penting dalam memupuk sikap disiplin siswa. Disiplin merupakan bagian dari solusi yang mampu menjadikan norma-norma aturan dapat teraplikasi secara benar dan tepat sasaran, sehingga proses pendidikan dan pengajaran di sekolah menjadi kondusif. Peran sekolah dalam membentuk disiplin siswa menjadi kebutuhan pokok bagi sekolah yang mendambakan kemajuan. Sekolah yang selalu menegakkan disiplin kepada siswanya maka akan mampu menjadi sekolah yang berkualitas.

Sikap disiplin harus dilakukan dengan terbiasa, anak akan melakukan aktifitasnya sesuai dengan aturan yang ada sehingga perilaku menyimpang dapat dikurangi. Kedisiplinan dapat memberi kenyamanan pada siswa dan guru serta menciptakan lingkungan yang kondusif untuk belajar serta perkembangan dari pengembangan diri sendiri dan pengarahan diri sendiri tanpa pengaruh atau kendali dari luar. Untuk dapat membentuk disiplin siswa dibutuhkan kerjasama yang baik antara guru, siswa dan lingkungan sekolah. Tata tertib merupakan pedoman bagi sekolah untuk menciptakan suasana sekolah yang aman, nyaman dan tertib sehingga pembelajaran terhindar dari perbuatan-perbuatan yang menyimpang.

Penegakan tata tertib di sekolah sangat penting dilakukan. Hal ini dikarenakan dengan melakukan implementasi tata tertib di sekolah dapat mengurangi tindakan-tindakan negatif dari siswa seperti terlambat datang sekolah atau kebiasaan membolos. Melakukan penegakan disiplin yang ketat melalui implementasi tata tertib dapat menjadikan siswa untuk terbiasa bersikap disiplin sehingga pelanggaran-pelanggaran di sekolah dapat dikurangi. Oleh karena itu, sekolah harus menjalankan tata tertib dengan konsisten baik dari guru maupun siswa sehingga mampu meningkatkan kualitas tingkah laku siswa.

Selain itu, orang tua selalu memikirkan cara yang tepat untuk menerapkan sikap disiplin bagi anaknya sejak usia dini sampai usia sekolah. Anak-anak diarahkan untuk belajar mengenai hal-hal yang baik, yang merupakan persiapan bagi masa depannya, sikap disiplin yang tertanam pada anak akan membuat mereka lebih berkonsentrasi belajar, sehingga anakanak tersebut berhasil di dalam sekolah. Sikap disiplin tumbuh bukan merupakan peristiwa mendadak yang terjadi seketika. Sikap disiplin tumbuh secara bertahap sedikit demi sedikit. Selain itu, sikap disiplin yang dibawa dari rumah akan sangat menentukan warna disiplin siswa di sekolah.

Rasa senang melihat keberhasilan anak dan kekecewaan melihat sikap anak yang buruk merupakan hal yang paling efektif dalam menerapkan disiplin pada anak. Lingkungan sekolah menerapkan sikap disiplin dilakukan dengan adanya pemberlakuan tata tertib sekolah. Tata tertib sekolah berlaku bagi semua siswa di sekolah itu. Guru merupakan orang tua di sekolah bagi semua siswa. Olehkarena guru sangat berperan sekali dalam keberhasilan membentuk perilaku siswa-siswi. Melalui tata tertib harus berusaha mampu menerapkan sikap disiplin pada setiap anak didiknya.

Guru yang realistis, menyadari ada kalanya membuat konsekuensi bagi pelanggar tata tertib sekolah. Tidak semua tata tertib akan diikuti dengan baik apabila tidak ada kemauan dengan pihak siswa untuk mematuhinya. Kesediaan siswa untuk mematuhi atau mengingkari 
tata tertib tersebut sangat dipengaruhi oleh konsekuensi atau akibatnya, baik positif maupun negatif. Sebagaimana diketahui, bahwa dalam proses pendidikan, hadiah dan hukuman merupakan akibat dari pematuhan dan pengingkaran terhadap tata tertib dan keduanya itu dikategorikan sebagai proses pendidikan.

Disiplin muncul dari kebiasaan hidup dan kehidupan belajar yang teratur serta mencintai dan menghargai pekerjaannya. Untuk itu, guru memerlukan pemahaman tentang landasan ilmu kependidikan dan keguruan, sebab dewasa ini rendahnya sopan santun dan rendahnya disiplin dalam proses pendidikan, yang dilakukan oleh peserta didik.

Amanatun mengatakan Sekolah merupakan tempat atau lembaga pendidikan yang mana siswa bukan saja hanya belajar mengenai ilmu tetapi juga diwajibkan harus mematuhi peraturan yang berlaku di sekolah demi membangun akhlak siswa dan memiliki karakter sebagaimana disebut sebagai siswa yang taat dan siswa yang disiplin. Setiap sekolah tentu memiliki peraturan demi terciptanya sikap disiplin siswa khususnya dalam sekolah tersebut,namun jika dilihat kenyataannya siswa belum sepenuhnya mematuhi tata tertib sekolah tersebut. Sebaliknya sebagian siswa masih tidak peduli dengan aturan tersebut, malah siswa tersebut beranggapan lebih baik dihukum atau diberi sanksi oleh Bapak/Ibu Guru yang ada disekolah dari pada mematuhi aturan yang telah dibuat oleh pihak sekolah.

Sebagian siswa jika dilihat pada kenyataannya, siswa terpengaruh oleh kemajuan zaman modern sekarang ini, siswa tersebut tidak merasa puas jika tidak melakukan kehendak sendiri, misalnya dalam berpakaian seragam sekolah. Seharusnya siswa tersebut harus mengikuti aturan yang telah dibuat bahwa dalam memakai seragam sekolah, baju tidak diperbolehkan sempit, celana tidak di potong, tidak memakai kaos kaki secara sembarangan, selain itu dalam hal penampilan siswa masih banyak yang memiliki rambut gondrong atau panjang khususnya bagi laki-laki dan wanita juga masih banyak yang melanggar aturan seperti halnya dalam berpakaian juga. Selain itu tata tertib sekolah yang tidak ditaati maraknya penggunaan HP ( handphone) di kelas pada saat kegiatan belajar mengajar, tidak melaksanakan tugas piket di kelas dengan baik atau membersihkan ruangan kelas, jika masalah tersebut kebiasaan dilakukan oleh siswa maka sikap disiplin siswa akan semakin menurun.

Sehubungan dengan rendahnya disiplin dalam menaati tata tertib sekolah juga akan mengakibatkan rendahnya mutu pendidikan, maka timbul pula pertanyaan lain, yaitu: Apakah tata tertib sekolah berpengaruh dalam meningkatkan rendahnya sikap disiplin tersebut? Dari latar belakang di atas, penulis tertarik mengadakan penelitian tentang : Pengaruh penerapan tata tertib sekolah terhadap tingkat kedisiplinan Siswa kelas X di SMA Persiapan Stabat Tahun Pembelajaran 2018/2019.

\section{METODE}

Penelitian eksperimen merupakan penelitian yang dimaksudkan untuk mengetahui ada tidaknya akibat dari "sesuatu" yang dikenakan pada subjek selidik. Suharsimi arikunto mengatakan penelitian ini termasuk dalam penelitian eksperimen. Dengan kata lain penelitian eksperimen mencoba meneliti ada tidaknya hubungan sebab akibat.

Penelitian ini dilaksanaan di SMA Swasta Persiapan Stabat Jln.Perniagaan No.31 A Stabat Kabupaten Langkat, penelitian ini dilaksanakan dari bulan mei sampai selesai.

Populasi pada penelitian ini adalah seluruh siswa kelas X SMA Persiapan stabat tahun 2018/2019 yang terdiri dari 7 kelas yang berjumlah 220 siswa. Untuk kebutuhan instrumen peneliti membentuk satu kelas sebagia sampel penelitian dengan jumlah 35 siswa. 
Sesuai dengan judul penelitian, variabel-variabel yang terdapat di dalam penelitian ini sebagai berikut: Pengaruh Tata Tertib Sekolah adalah variabel bebas atau variabel (X), Sugiono menjelaskan mengenai variabel bebas sebagai berikut:

"Variabel ini sering disebut sebagai variabel stimulus, input, predictor dan antecedent. Dalam bahasa Indonesia sering disebut sebagai variabel bebas. Variabel bebas adalah variabel yang menjadi sebab timbulnya atau berubahnya variabel dependen (variabel terikat). Jadi variabel independent adalah variabel yang mempengaruhi”.

Indikator dari variabel $\mathrm{X}$ di atas adalah sebagai berikut :

1. Pengertian Tata tertib sekolah

2. Tujuan tata tertib sekolah

3. Peran dan Fungsi Tata Tertib Sekolah

4. Sikap Kepatuhan Siswa Terhadap Tata Tertib Sekolah

Sedangkan Kedisiplinan Siswa adalah variabel terikat atau variabel Y, menjelaskan tentang variabel terikat ini sebagai berikut :

"Sering disebut sebagai variabel respon, output, criteria, konsekuen. Dalam bahasa Indonesia sering disebut sebagai variabel terikat. Variabel terikat merupakan variabel yang dipengaruhi atau yang menjadi akibat, karena adanya variabel bebas"

Indikator dari variabel Y diatas adalah sebagai berikut :

1. Pengertian Disiplin Siswa

2. Disiplin Siswa Di Sekolah

3. Disiplin Siswa Di Kelas

Untuk menunjang kevalidan dan keilmian data yang penulis dapatkan, maka penulis menggunakan beberapa instrument penelitian sebagai alat bantu memperoleh data dari obyek penelitian. Instrument penelitian adalah alat bantu yang dipilih dan digunakan oleh peneliti dalam kegiatannya mengumpulkan data agar kegiatan tersebut menjadi sistematis dan lebih mudah. Adapun Instrumen Penelitian yang penulis pergunakan dalam penelitian ini adalah observasi, angket/kuesioner, dan skala pengukuran.

Dalam penelitian kuantitatif, teknik analisis data merupakan kegiatan setelah data dari seluruh responden atau sumber data lain terkumpul. Kegiatan dalam analisis data adalah: Mengelompokkan data berdasarkan variabel dan jenis responden, mentabulasi data berdasarkan variabel dari seluruh responden, menyajikan data tiap variabel yang diteliti, melakukan perhitungan untuk menjawab rumusan masalah, dan melakukan perhitungan untuk menguji hipotesis yang telah diajukan. Kegiatan dalam analisis data adalah: mengelompokkan data berdasarkan variabel dan jenis responden, menyajikan data tiap variabel yang diteliti, melakukan perhitungan untuk menjawab rumusan masalah.

Hipotesis dari setiap penelitian perlu diuji. Tujuan dari pengujian tersebut adalah untuk membuktikan kebenaran dari hipotesis yang telah dirumuskan sebelumnya. Uji hipotesis dalam penelitan ini menggunakan teknik analisis regresi sederhana. Penentuan uji regresi dalam penelitian ini menggunakan software SPSS 16. Analisis regresi sederhana dapat dibuat dengan persamaan sebagai berikut :

$\mathrm{Y}=\mathrm{a}+\mathrm{bX} \quad$ Sumber : (Sudjana, 312)
$a=\frac{\left(\left(\sum Y_{i}\right)\left(\sum X_{i}^{2}\right)\right)-\left(\left(\sum X_{i}\right)\left(\sum X_{i} Y_{i}\right)\right)}{n \sum X_{i}^{2}-\left(\sum X_{i}\right)^{2}}$


$b=\frac{n \sum X_{i} Y_{i}-\left(\sum X_{i}\right)\left(\sum Y_{i}\right)}{n \sum X_{i}^{2}-\left(\sum X_{i}\right)^{2}}$

Keterangan :

$\mathrm{Y}=$ populasi dalam variabel terikat

$\mathrm{X}=$ populasi dalam variabel bebas

$\mathrm{a}=$ Koefisien (nilai Y apabila $x=0$ )

$\mathrm{b}=$ Koefisien regresi

Uji keberartian regresi dapat disimpulkan pada tabel anava sebagai berikut :

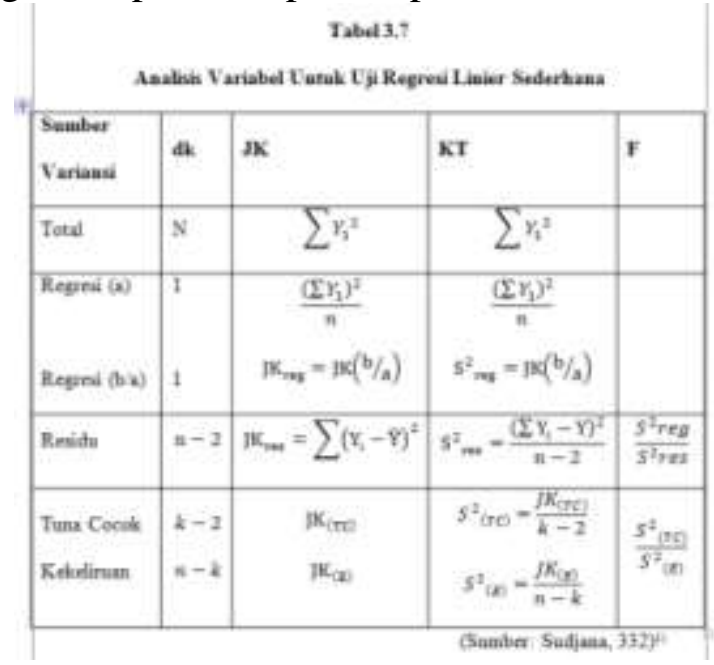

Dengan:

$I K_{(E)}=\sum_{x}\left\{\sum y^{2}-\frac{(\Sigma y i)}{n}\right\}$

$I K_{(b / a)}=b \sum x i y i-\frac{\left(\sum x i\right)\left(\sum y i\right)}{n}$

$I K_{(r e s)}=\sum y i^{2}-\frac{\left(\sum y i\right)^{2}}{n}-J K_{(b / a)}$

$I K_{(T C)}=J K_{(r e s)}-J K_{(E)}$

Jika $\alpha=0,05$ dengan $\mathrm{dk}$ pembilang $\mathrm{k}-2$ dan $\mathrm{dk}$ penyebut $\mathrm{n}-\mathrm{k}$ maka diperoleh $F_{\text {tabel }}=F_{0,95(k-2)(n-k)}$ untuk uji kelinieran jika $F_{\text {hitung }}<F_{\text {tabel }}$ maka peesamaan regresi diterima.

Pengambilan keputusan didasarkan pada uji regresi yang diperoleh, yaitu : Pengambilan keputusan dan penarikan kesimpulan terhadap uji hipotesis dilakukan pada taraf siginifikansi $5 \%$ atau 0,05. Jika nilai Signifikansi $<0,05$ atau $t_{\text {hitung }}>t_{\text {tabel }}$, artinya variabel bebas berpengaruh terhadap variabel terikat dan jika nilai Signifikansi $>0,05$ atau $t_{\text {hitung }}<t_{\text {tabel }}$ maka sebaliknya.

\section{HASIL DAN PEMBAHASAN}

\section{Gambaran Umum Tempat Penelitian}

SMA Swasta Persiapan Stabat termasuk salah satu sekolah menengah atas berstatus swasta yang ada di kota Stabat kabupaten Langkat. Sekolah SMA Swasta Persiapan Stabat telah diakreditasi oleh tim atau badan akriditasi sekolah dan memperoleh nilai akriditasi yang 
sangat baik yaitu terakreditasi A. SMA Persiapan Stabat berdiri diatas tanah seluas $6800 \mathrm{~m}$ yang berlokasi di jln Hib Tembeleng kecamatan Stabat kabupaten Langkat. Jumlah kelas yang ada di SMA Persiapan Stabat yaitu kelas X terdapat 7 kelas, kelas XI terdapat 7 kelas dan begitu juga kelas XII terdapat 7 kelas. Kepemimpinan kepala sekolah SMA Persiapan Stabat dipimpin oleh bapak Irwan Amri. Berdasarkan data yang diperoleh dari staf tata usaha adapun visi, misi SMA Persiapan Stabat sebagai berikut:

1. Visi

Mulia dalam perbuatan, unggul dalam pengetahuan yang dilandasi keimanan dan ketaqwaan dalam ilmu pengetahuan dan teknologi.

2. Misi
a. Meningkatkan sistim belajar yang efektif
b. Meningkatkan keimanan, ketaqwaan dan ilmu pengetahuan
c. Mengembangkan bakat dan kreatifitas siswa

Peraturan dan Disiplin SMA Persiapan Stabat

\section{a. Kewajiban Siswa}

$>$ Pukul 07.15 siswa sudah hadir disekolah

$>$ Keterlambatan hadir kurang dari 10 menit diperbolehkan masuk kelas/ mengikuti pelajaran seijin guru piket

> Apabila siswa akan meninggalkan sekolah sebelum jam belajar berakhir oleh karena sakit atau ijin keperluan lain, harus meminta ijin kepada semua guru bidang sutdi yg ditinggalkan lalu meminta ijin kepada guru piket.

$>$ Wajib mengikuti kegiatan belajar mengajar sejak jam pertama hingga jam terakhir, serta pulang secara bersama- sama setelah tanda bel pelajaran terakhir dibunyikan

$>$ Wajib menikuti upacara yang ditentukan oleh sekolah.

b. Pakaian Seragam Sekolah

$>$ Mengenakan pakaian osis serta atribut yang lengkap

$>$ Senin, selasa memakai putih abu-abu, rabu kamis batik dan jum'at sabtu pramuka.

$>$ Sepatu hitam dan kaos kaki panjang berwarna putih

$>$ Baju dalam keadaan rapi dan bersih

$>$ Mengenakan topi saat upacara bendera

c. Lingkungan Sekolah

$>$ Ikut menjaga kebersihan dan keindahan lingkungan sekolah

$>$ Membuang sampah pada tempat yang disediakan

$>$ Tidak melakukan coret- coret dinding atau meja belajar

$>$ Tidak merusak sarana- prasarana yg ada disekolah

\section{d. Etika Dan Sopan Santun}

Menghormati kepala sekolah, guru dan karyawan SMA Persiapan Stabat

$>$ Bersikap sopan santun terhadap warga sekolah

$>$ Bagi siswa putri tidak berdandan secara mencolok dan tidak menggunakan perhiasan secara berlebihan

$>$ Menjaga keamanan dan ketertiban disekolah maupun sepulang sekolah

$>$ Saling menghormati sesama siswa

e. Larangan- Larangan

$>$ Meninggalkan sekolah sebelum jam pelajaran berakhir

$>$ Berkeliaran diluar kelas saat jam pelajaran berlangsung

$>$ Merokok 
Berjudi

> Melakukan pelecehan hal yang tidak senonoh

$>$ Mengambil barang milik sekolah

$>$ Berkelahi

$>$ Membawa sepada motor tidak lengkap

Membawa senjata tajam

\section{f. Sanksi- Sanksi}

1. Peringatan secara lisan dan penindakan secara langsung

2. Peringatan scara tertulis

3. Pemanggilan orang tua

4. Skorsing tidak boleh mengikuti jam pelajaran

5. Dikeluarkan dari sekolah dengan tidak hormat.

\section{Kegiatan Siswa SMA Persiapan Stabat}

Waktu pembelajaran di SMA Persiapan Stabat setiap harinya berlangsung selama 8 jam pelajaran. Seluruh siswa wajib mengikuti segala bentuk kegiatan yang ada di SMA Persiapan Stabat. Berikut rincian kegiatan harian siswa SMA Persiapan Stabat dari hari Senin sampai dengan hari Sabtu selama 8 jam pelajaran perharinya.

$$
\text { Tabel } 4.1
$$

Kegiatan Harian Siswa SMA Persiapan Stabat

\begin{tabular}{|c|c|c|c|c|}
\hline Hari & No & Waktu & Kegiatan & Tempat \\
\hline \multirow{10}{*}{ Senin } & 1 & $07.30-08.30$ & Upacara Bendera & Halaman Sekolah \\
\hline & 2 & $08.30-09.10$ & Pembelajaran & Ruang Kelas \\
\hline & 3 & $09.10-09.50$ & Pembelajaran & Ruang Kelas \\
\hline & 4 & $09.50-10.10$ & Istirahat & Lingkungan Sekolah \\
\hline & 5 & $10.10-10.50$ & Pembelajaran & Ruang Kelas \\
\hline & 6 & $10.50-11.30$ & Pembelajaran & Ruang Kelas \\
\hline & 7 & $11.30-11.45$ & | Istirahat & Lingkungan Sekolah \\
\hline & 8 & $11.45-12.25$ & Pembelajaran & Ruang Kelas \\
\hline & 9 & $12.25-13.05$ & Pembelajaran & Ruang Kelas \\
\hline & 10 & $13.05-13.45$ & Pembelajaran & Ruang Kelas \\
\hline \multirow{9}{*}{$\begin{array}{l}\text { Selasa } \\
\text { s/d } \\
\text { Kamis } \\
\text { dan } \\
\text { Sabtu }\end{array}$} & $\mid 1$ & $07.30-08.30$ & \begin{tabular}{|l|} 
Apel Pagi / Sholat \\
Dhuha
\end{tabular} & \begin{tabular}{|l|} 
Halaman \\
Sekolah/Mushola
\end{tabular} \\
\hline & 2 & $08.30-09.10$ & Pembelajaran & Ruang Kelas \\
\hline & 3 & $09.10-09.50$ & Pembelajaran & Ruang Kelas \\
\hline & 4 & $09.50-10.10$ & Istirahat & Lingkungan Sekolah \\
\hline & 5 & $10.10-10.50$ & Pembelajaran & Ruang Kelas \\
\hline & 6 & $10.50-11.30$ & Pembelajaran & Ruang Kelas \\
\hline & 7 & $11.30-11.45$ & | Istirahat & Lingkungan Sekolah \\
\hline & 8 & $11.45-12.25$ & Pembelajaran & Ruang Kelas \\
\hline & 9 & $12.25-13.05$ & Pembelajaran & Ruang Kelas \\
\hline
\end{tabular}




\section{Bentuk-Bentuk Pelanggaran Kedisiplinan Siswa SMA Persiapan Stabat}

Berdasarkan hasil pengamatan yang telah dilakukan oleh peneliti, bentuk-bentuk pelanggaran kedisiplinan yang dilakukn oleh siswa adalah:

a. Tidak masuk kelas tanpa ijin atau keterangan.

b. Tidak membawa baju olah raga saat pelajaran olah raga.

c. Terlambat hadir di sekolah.

d. Sengaja dating terlambat untuk menghindari apel pagi.

\section{Faktor Penyebab Pelanggaran Kedisiplinan}

Penyebab pelanggaran kedisiplinan siswa yaitu berasal dari diri siswa itu sendiri, diantaranya yaitu karena merasa jenuh, dan malas, serta karena belum memahami peraturanperaturan yang ada yang dianggap terlalu banyak. Selain itu, menurut siswa peraturan yang dibuat di sekolah terlalu memberatkan siswa. berdasarkan hasil wawancara dengan salah satu siswa kelas X, siswa tersebut mengungkapkan bahwa peraturan yang dibuat oleh sekolah terlalu memberatkan dan beberapa kurang sesuai.

\section{Solusi Pelanggaran Kedisiplinan Siswa}

Solusi pelanggaran kedisiplinan siswa yang diterapkan di SMA Persiapan Stabat diantaranya melalui penerapan peraturan, hukuman, penghargaan.

a. Penerapan Peraturan

Pemberian peraturan berupa tata tertib sekolah yang disusun dalam bentuk spanduk yang dipajang di dinding luar kantor guru, hal ini dimaksudkan agar siswa dapat lebih mudah memahami apa saja peraturan kedisiplinan yang harus di patuhi oleh seluruh siswa.

b. Hukuman

Pemberian hukuman dilakukan kepada siswa yang melakukan pelanggaran kedispilinan. Hal ini dimaksudkan agar siswa yang melakukan pelanggaran dapat merasa jera dan tidak mengulangi pelanggaran yang dilakukan.Bentuk pemberian hukuman berbeda sesuai dengan bentuk pelanggaran yang dilakukan, seperti siswa yang tidak membawa baju olah raga tidak diperbolehkan mengikuti kegiatan olah raga dan tidak mendapatkan nilai, serta pemeberian skor sanksi pelanggaran bagi siswa yang merokok, datang terlambat, diberikan nasehat, dan lain-lain.

c. Penghargaan

Pemberian penghargaan kepada siswa yang disiplin juga dilakukan sebagai bentuk solusi preventif dari pelanggaran kedisiplinan siswa. Pemberian penghargaan kepada siswa diberikan melalui pujian agar siswa yang memperoleh pujian dapat lebih termotivasi lagi untuk disiplin dan bapat mendorong siswa yang tidak disiplin untuk disiplin.

Dalam sub bahasan ini peneliti akan menyajikan hasil angket yang telah peneliti sebarkan kepada 32 responden yaitu siswa-siswi kelas X SMA Persiapan Stabat mengenai penerapan tata tertib sekolah dan kedisiplinan siswa di SMA Persiapan Stabat.

Untuk mendapatkan hasil dari jawaban angket, langkah yang telah ditempuh adalah memberikan angket penerapan tata tertib sekolah dan kedisiplinan siswa kepada seluruh responden dalam hal ini adakah siswa-siswi kelas X SMA Persiapan Stabat yang telah ditentukan sebagai sampel penelitian. Setelah angket diberikan dan dijawab oleh responden, maka pada tahap berikutnya adalah penarikan atau pengumpulan angket dan penilaian dari masing - masing alternatif jawaban. Tabel 4.1 berikut ini menyajikan hasil angket penerapan tata tertib sekolah dan kedisiplinan siswa di SMA Persiapan Stabat. 
Tabel 4.2

Hasil Angket Pener apan Tata Tertib Sekolah dan Ked isiplinan Siswa

\begin{tabular}{|c|c|c|c|}
\hline No & $\begin{array}{c}\text { Kode } \\
\text { Responden }\end{array}$ & $\begin{array}{c}\text { Total Skor } \\
\text { Item Tata Tertib }\end{array}$ & $\begin{array}{c}\text { Total Skor } \\
\text { Item Kedisiplinan }\end{array}$ \\
\hline 1 & A1 & 45 & 55 \\
\hline 2 & A2 & 65 & 60 \\
\hline 3 & A3 & 50 & 50 \\
\hline 4 & A4 & 50 & 70 \\
\hline 5 & A5 & 55 & 60 \\
\hline 6 & A6 & 55 & 65 \\
\hline 7 & A7 & 75 & 65 \\
\hline 8 & A8 & 60 & 60 \\
\hline 9 & A9 & 83 & 65 \\
\hline 10 & A10 & 60 & 80 \\
\hline 11 & A11 & 65 & 55 \\
\hline 12 & A12 & 75 & 85 \\
\hline 13 & A13 & 75 & 80 \\
\hline 14 & A14 & 76 & 85 \\
\hline 15 & A15 & 75 & 85 \\
\hline 16 & A16 & 80 & 85 \\
\hline 17 & A17 & A18 & 55 \\
\hline 18 & A19 & 50 & 85 \\
\hline 19 & 50 & 50 \\
\hline
\end{tabular}

Dari tabel di atas diketahui persentase pernerapan tata tertib dan kedisiplinan siswa berturut-turut adalah $75 \%$ dan $71 \%$. Angka persentase sebesar $75 \%$ untuk penerapan tata tertib menunjukkan bahwa penerapan tata tertib di SMA Persiapan Stabat tergolong dalam kriteria baik dan angka persentase sebesar $71 \%$ untuk kedisiplinan siswa menunjukkan bahwa kedisiplinan siswa di SMA Persiapan Stabat terutama pada kelas X juga tergolong dalam kriteria baik, hal ini mengindikasikan bahwa jika penerapan tata tertib di sekolah SMA Persiapan Stabat berjalan dengan baik maka kedisiplinan siswa di sekolah itu juga akan baik.

\section{Uji Hipotesis}

Setelah diperolehnya data angket pernerapan tata tertib dan kedisiplinan siswa kelas X SMA Persiapan Stabat, tahap selanjutnya adalah menguji hipotesis yang telah ditetapkan. Pengujian hipotesis dalam penelitian ini menggunakan teknik analisis regeresi sederhana dan dalam perhitungannya menggunakan aplikasi software SPSS. 16, tabel 4.3 dan tabel 4.4 berikut ini adalah output analisis regresi sederhan menggunakan aplikasi software SPSS. 16.

$$
\text { Tabel } 4.3
$$

Output Anov a Uji Hip otesis dengan Analisis Regresi Sederhana

ANOVA $^{\text {b }}$

\begin{tabular}{|c|c|c|c|c|c|c|}
\hline \multicolumn{7}{|c|}{ ANOVA $^{\circ}$} \\
\hline \multicolumn{2}{|c|}{ Model } & $\begin{array}{l}\text { Sum of } \\
\text { Squares }\end{array}$ & df & $\begin{array}{l}\text { Mean } \\
\text { Square }\end{array}$ & $\mathrm{F}$ & Sig. \\
\hline 1 & Regression & 623.537 & 1 & 623.537 & 5.092 & $.031^{\mathrm{a}}$ \\
\hline & Residual & 4040.635 & 33 & 122.443 & & \\
\hline & Total & 4664.171 & 34 & & & \\
\hline
\end{tabular}

a. Predictors: (Constant), TataT ertib

b. Dependent Variable: Kedisiplinan 


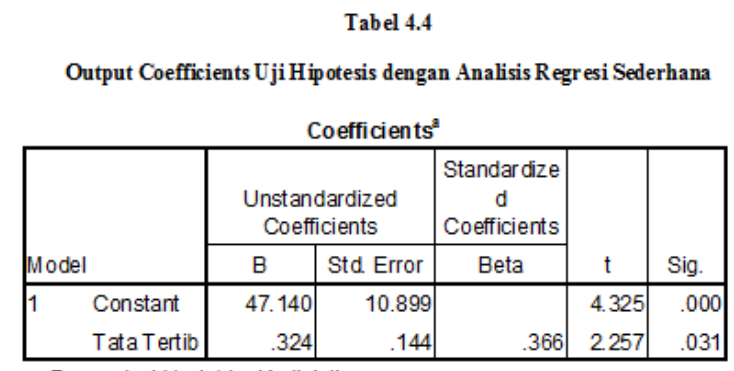

a. Dependent Variable: Kedisiplinan

Berdasarkan Tabel 4.3 di atas diperoleh nilai $\mathrm{F}_{\text {hitung }}$ sebesar 5,09 dengan tingkat signifikansi 0,03 . Sedangkan nilai $F_{\text {tabel }}$ sebesar 1,77 sehingga diketahui $F_{\text {hitung }}>F_{\text {tabel }}$ dan nilai siginifikansi $0,03<0,05$ maka model regresi dapat dipakai untuk memprediksi nilai variabel terikat melalui variabel bebas jika dimanipulasi. Pada kolom B baris constant didapat nilai 47,14 dan pada kolom B baris tata tertib didapat nilai 0,32. Sehingga dari nilai-nilai tersebut dapat dibentuk sebuah persamaan regresi linear yaitu $Y=47,14+0,32 X$. Dari tabel tersebut juga diketahui nilai $t_{\text {hitung }}=4,32$ dengan $\mathrm{dk}=34$ maka diperoleh nilai $\mathrm{t}_{\text {tabel }}=2,03$ sehingga diketahui nilai $t_{\text {hitung }}>t_{\text {tabel }}$. Karena nilai $t_{\text {hitung }}>t_{\text {tabel }}$ maka hal ini menunjukan bahwa hipotesis yang telah ditetapkan dapat diterima yaitu terdapat pengaruh tata tertib sekolah terhadap tingkat kedisiplinan siswa SMA Swasta Persiapan Stabat.

\section{SIMPULAN}

Berdasarkan hasil penelitian yang diuraikan maka dapat diambil kesimpulan bahwa penerapan tata tertib menunjukkan bahwa penerapan tata tertib di SMA Persiapan Stabat tergolong dalam kriteria baik dan angka persentase sebesar $71 \%$ untuk kedisiplinan siswa menunjukkan bahwa kedisiplinan siswa di SMA Persiapan Stabat terutama pada kelas X juga tergolong dalam kriteria baik, hal ini mengindikasikan bahwa jika penerapan tata tertib di sekolah SMA Persiapan Stabat berjalan dengan baik maka kedisiplinan siswa di sekolah itu juga akan baik.

\section{REFERENSI}

Kompri, 2014. Manajemen Sekolah Teori dan Praktek. Bandung: alfabeta. Langgulung,

Hasan. 2014. Manusia Pendidikan.Jakarta: PT Al -Husna Baru.

Moleong, Lexy. 2014. Metode Penelitian Kualitatif .Bandung: Rosda.

Mustari, Mohamad. 2014.Nilai karakter Refleksi untuk Pendidikan.Jakarta: rajawali Pers.

Nazir, Moh. 2014.Metode Penelitian. Bogor: Ghalia Indonesia.

Naim,Ngainun.2012. Optimalisasi Peran Pendidikan dalam Pengembangan Ilmu \& Pembentukan Karakter Bangsa, Yogyakarta: Ar-Ruzz Media.

Rifa'i, Muhammad. 2013.Sosiologi Pendidikan.Yogyakarta: Ar-ruzz media

S, Azwar. 2013. Reabilitas dan Validitas. Yogyakarta: Pustaka Pelajar. 
Schaefer,Charles. 2011. Membimbing Mendidik dan Mendisiplinkan Anak Secara Efektif. Jakarta: Radar Jaya Offset.

Silvia, rimm. 2013. Mendidik dan Menerapkan Disiplin pada Anak Prasekolah.Jakarta: Grame

Soedjono.2014. Dasar-Dasar Tata Tertib Sekolah.jakarta: PT Raja Grafindo Persada.

Sukmadinata syaodih nana . 2010. Metode Penelitian Pendidikan. Bandung : PT Remaja Rosdakarya

Suryosubroto. 2016. Menejemen pendidikan sekolah. Jakarta: PT Reneka Cipta.

Tulus Tuu, 2013. peran disiplin Pada Prilaku dan Prestasi siswa. Jakarta: Grafindo.

Wiyani, Ardy, Novan.2016. Manajemen Kelas.Yogyakarta: Ar- Ruzz Media: Angkasa.

Undang- undang: Undang-Undang Republik Indonesia No.20 Tahun 2003 tentang Sistem Pendidikan. 